\title{
Development of Augmented Reality Traditional Musical Education Applications
}

\author{
Zulkifli Syahrir Ramadhan (i) \\ Software Engineering Technology, \\ Agriculture Polytechnic of \\ Samarinda, 75242, Indonesia \\ zulkiflisyahrir56@gmail.com
}

\author{
Reza Andrea (10* \\ Software Engineering Technology, \\ Agriculture Polytechnic of \\ Samarinda, 75242, Indonesia \\ reza.andrea@gmail.com \\ *Corresponding author
}

\author{
Suswanto \\ Software Engineering Technology, \\ Agriculture Polytechnic of \\ Samarinda, 75242, Indonesia \\ Susanto.attala@gmail.com
}

Submitted: 2021-10-03; Revised: 2021-20-20; Accepted: 2022-02-27; Published: 2022-03-01

\begin{abstract}
Technology that is developing very rapidly today is no exception in the world of education, the convenience offered by technology cannot be denied by shifting the way children learn who were born and raised in the digital era. In the field of education, augmented reality technology has been widely implemented, such as applications that use augmented reality book aids. This study aims to create an alternative application as a learning medium for the introduction of traditional musical instruments with a multimedia development method by an elementary school educational institution. In this study, the augmented reality method used is Image Based Tracking, which uses images as markers. The tool that helps in making AR is the Vuforia SDK which is used as a storage area marker. By doing this research, the results obtained in the form of an Augmented Reality Traditional Musical Instrument Recognition application that runs on the Android platform and respondent testing using the User Acceptance Testing (UAT) method with a value of $86 \%$.
\end{abstract}

Keywords - Technology, Augmented Reality, Image Based Tracking, UAT, Traditional Musical Instruments.

\section{INTRODUCTION}

Technology that is developing very rapidly at this time brings many positive impacts but not infrequently it also brings negative things. No exception in the world of education, the convenience offered by technology cannot be denied by shifting the way children learn who were born and raised in the digital era. In the field of education, augmented reality technology has been widely applied, such as applications that use augmented reality books, games, object modeling and observation-based learning (Muhammad Edya Rosadi \& Indu Indah Purnomo, 2018).

As one of the big cities in Indonesia, Samarinda has many students who have been introduced to various kinds of musical instruments. However, musical instruments that are often introduced are external musical instruments, such as violin, piano, drums, bass, saxophone and others. Traditional musical instruments are important and need to be learned by elementary school students because they are one of the local cultures that must be preserved by the next generation of the nation. Educational books about traditional Indonesian musical instruments in the schoolbook curriculum already exist in grade 4 elementary school, it's just that books that discuss traditional Indonesian musical instruments specifically and are able to attract students to want to read and learn are still limited (Rustandy et al 2017).

In this study, the augmented reality method used is Marker Based Tracking, Image Based Tracking, which uses images as markers. The tools that help in this stage of making augmented reality are the Vuforia SDK which is used as a marker storage area. Making this application is the use of Augmented Reality technology and educational applications and the media is a smartphone.

Some cases are relevant to the research that will be made, in the journal Mulyana et al (2020) they apply augmented reality as a medium for learning to know gamelan musical instruments. However, it is not explained that the application has other features such as quizzes, music, or the sound of objects in the application, then the marker used is also in the form of a card, while in the application that will be made using a marker in the form of a book containing pictures so that students who use it can also see the comparison. From the original object image in 2D with 3D form and the created object will also be made to be played as well as the addition of information and music sound in the application.

This application will later display Augmented Reality as the object and quizzes as the game. In addition to presenting and giving quizzes, the game also scores each answer. The objects in this application will be various traditional musical instruments in Indonesia which are taken from the Art, Culture, and Craft (SBdP) textbooks. That way this application is intended for elementary school students.

\section{LITERATURE REVIEW}

\section{A. Study of literature}

Several studies are used as guidelines and references in making this application, among others. In the research of Nugraha et al (2014) in their research entitled Utilization of Augmented Reality for Learning Introduction to Piano Musical Instruments. Aims to make Augmented Reality technology useful as a learning method in the field of introducing theory about piano musical instruments. The benefit of this research is that users can learn more fun in 
an easy way. In Setyawan's research (2016) entitled Analysis of the Use of Marker Tracking Methods in Augmented Reality of Traditional Central Java Musical Instruments which discusses comparative analysis between the two marker tracking methods, namely marker based tracking and marker less which aims to have a success rate in bringing up good objects. So that research will be carried out to find out the effectiveness of the marker tracking method that is better and things that can affect the success rate of augmented reality applications in bringing up objects by looking at the parameters that influence it, namely the distance of the marker and the color used to be used as a marker in augmented reality. In (2018), in his research entitled Design and Build of Learning Media for Banjar Tribe Art and Culture Based on Augmented Reality which aims to attract children's interest in learning about the arts and culture of the Banjar area.

The benefits provided are that children's interest and knowledge in learning local culture and arts increases. (Muhammad Edya Rosadi \& Indu Indah Purnomo, 2018). In his research entitled Introduction to Bamboo Musical Instruments Using 3D Augmented Reality. Using the waterfall development method. The purpose of this research is to make Augmented Reality bamboo music so that it is known by anyone. The benefits provided are as a form of education for early childhood and the wider community who are starting to leave this traditional culture. (Kurniawan et al 2019). In a study from Mulyana et al (2020) entitled Design of Augmented Reality Learning Media Knowing the Gamelan Musical Instrument that uses the Markerless method and aims to make it easier for those who want to learn or know basically about the gamelan musical instrument itself. Then the benefits provided are that it makes it easier for those who want to learn the gamelan musical instrument which is actually difficult to find in many places. Previous research is different from the current research with the comparison shown in Table 1.

Table 1. Comparison Table

\begin{tabular}{|c|c|c|}
\hline Authors & Research Title & Summary \\
\hline $\begin{array}{l}\text { Nugraha, } \\
\text { Iwan Setya } \\
\text { Satoto, } \\
\text { Kodrat Iman } \\
\text { Martono, } \\
\text { Kurniawan } \\
\text { Teguh } \\
2014 \\
\end{array}$ & $\begin{array}{l}\text { Utilization of } \\
\text { Augmented } \\
\text { Reality for } \\
\text { Learning } \\
\text { Introduction to } \\
\text { Piano Musical } \\
\text { Instruments }\end{array}$ & $\begin{array}{l}\text { This developed } \\
\text { research } \\
\text { focuses on the } \\
\text { introduction of } \\
\text { the piano }\end{array}$ \\
\hline $\begin{array}{l}\text { Risyan Arief } \\
\text { Setyawan and } \\
\text { Afdhol Dzikri } \\
2016\end{array}$ & $\begin{array}{l}\text { Analysis of the } \\
\text { Use of Marker } \\
\text { Tracking } \\
\text { Methods on } \\
\text { Augmented } \\
\text { Reality } \\
\text { Traditional } \\
\text { Musical } \\
\text { Instruments of } \\
\text { Central Java }\end{array}$ & $\begin{array}{l}\text { This study } \\
\text { focuses on } \\
\text { analyzing the } \\
\text { two methods } \\
\text { of marker } \\
\text { tracking that } \\
\text { are assembled } \\
\text { on traditional } \\
\text { musical } \\
\text { instruments. }\end{array}$ \\
\hline
\end{tabular}

\begin{tabular}{|c|c|c|}
\hline $\begin{array}{l}\text { Muhammad } \\
\text { Edya Rosadi } \\
\text { \& Indu } \\
\text { Indah } \\
\text { Purnomo } \\
2018\end{array}$ & $\begin{array}{l}\text { Design and Build } \\
\text { Learning Media of } \\
\text { Banjar Tribe Art } \\
\text { and Culture Based } \\
\text { on Augmented } \\
\text { Reality }\end{array}$ & $\begin{array}{l}\text { This research } \\
\text { focuses on } \\
\text { attracting } \\
\text { children's } \\
\text { interest to learn } \\
\text { about the arts } \\
\text { and culture of } \\
\text { the Banjar area }\end{array}$ \\
\hline $\begin{array}{l}\text { Kurniawan, } \\
\text { et al } \\
2019\end{array}$ & $\begin{array}{l}\text { Introduction to } \\
\text { Bamboo Musical } \\
\text { Instruments Using } \\
\text { 3D Augmented } \\
\text { Reality }\end{array}$ & $\begin{array}{l}\text { This research } \\
\text { focuses on } \\
\text { providing } \\
\text { education to early } \\
\text { childhood and the } \\
\text { wider community } \\
\text { who are starting to } \\
\text { leave traditional } \\
\text { culture. }\end{array}$ \\
\hline $\begin{array}{l}\text { Yunita } \\
\text { Agustin } \\
\text { Mulyana, et al } \\
2020\end{array}$ & $\begin{array}{l}\text { Design and Build } \\
\text { Augmented } \\
\text { Reality Learning } \\
\text { Media Getting to } \\
\text { Know the } \\
\text { Gamelan Musical } \\
\text { Instrument }\end{array}$ & $\begin{array}{l}\text { The research } \\
\text { developed is } \\
\text { focused on } \\
\text { making it easier } \\
\text { for those who } \\
\text { want to learn or } \\
\text { know the basics } \\
\text { about the gamelan } \\
\text { musical } \\
\text { instrument itself. }\end{array}$ \\
\hline
\end{tabular}

Comparison of this paper, this application focuses on learning traditional music and attracts students' interest in learning by adding features and types of traditional musical instruments in the application and introducing Augmented Reality technology.

\section{B. Development}

Teaching activities involve the role of a teacher in the context of seeking to create a harmonious communication network between the teacher himself and the learner. (Wandah Wibawanto \& Kreatif, 2017). While the notion of interactive is related to two-way communication or more of the communication components. (Prasetyo, 2020).

\section{Traditional Musical Instruments}

Traditional musical instruments are typical musical instruments found in regions throughout Indonesia. There are so many types, because almost every region has its own musical instrument. Traditional musical instruments are certain to have them, so to learn or practice we must join one of the places that provide them. (Faisal et al 2018).

Musical instruments are instruments or tools that are intentionally created or adapted with the aim of producing musical sounds. Although in principle, anything that can produce sound with certain tones played by musicians or musicians can already be said that the instrument is a musical instrument, but specifically a tool made for the sole purpose of music. (Setyawan \& Dzikri, 2016).

\section{Augmented Reality}

This Augmented Reality technology enters information into a system then the information is called and displayed 
back in digital visual form as if it were in the real world. This can help users recognize an object in more detail without seeing the real object of the object. (Sofian et al 2020). An illustration of Augmented Reality can be seen in Picture 1

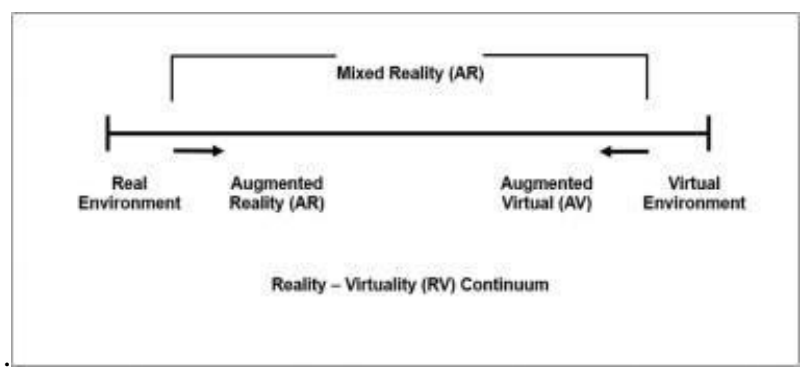

Picture 1. Illustration of Augmented Reality

Basically, the working principle of Augmented Reality is tracking and reconstruction. At first the marker was detected using a camera. Detection methods can involve various algorithms, such as edge detection, or other image processing algorithms. The data obtained from the tracking process is used in the reconstruction of the coordinate system in the real world. In addition to adding objects into the real environment, Augmented Reality can also remove real objects in virtual form. By covering the real object with a graphic design according to its environment, the real object will be hidden from the user (Judge, 2018). The process can be seen in Picture 2.

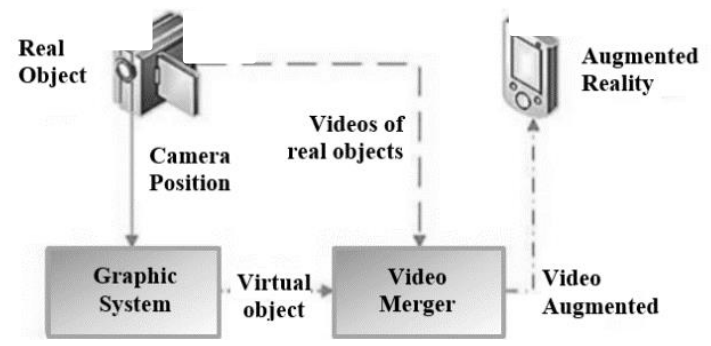

Picture 2. How Augmented Reality (AR) Works

\section{E. Marker Based Tracking / Image Based Tracking)}

Image Based Tracking is part of Marker based tracking which is an augmented reality method that recognizes markers and identifies patterns from these markers to add a virtual object to the real environment (Chari, 2008) in the journal (Satria \& Prihandoko, 2018).

The marker is a black and white square illustration with bold black sides, a black pattern in the center of the square and a white background. (Satria \& Prihandoko, 2018). From the definition above, Augmented Reality Marker can be described as Picture 3.

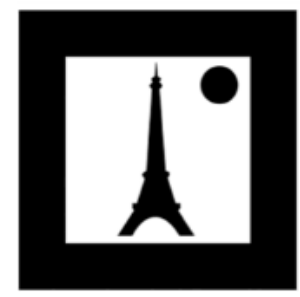

Picture 3. Marker Example

\section{F. 3 Dimensional (3D) Modeling}

Three-dimensional (3D) modeling or also known as meshing is the process of making a mathematical representation of a three-dimensional surface of an object with certain software. The product of the modeling is called a 3D model. The 3D model can be displayed as a two-dimensional image through a process called 3D rendering. A 3D model is represented by a collection of points in $3 \mathrm{D}$, connected by various geometric entities, such as triangles, lines, curved surfaces, and so on (Ernawati et al. 2017). This can be seen in picture 4 .

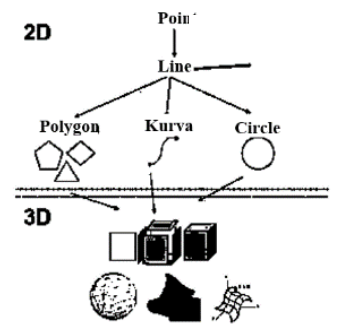

Picture 4. Comparison of 2D and 3D Objects

\section{G. Vuforia Software Development Kit (SDK)}

Vuforia is an Augmented Reality Software Development Kit (SDK) that is used on mobile devices to create Augmented Reality applications. This SDK uses computer vision technology to recognize and track target images and simple 3D objects in real-time. With this capability, it allows developers to make the position and orientation of virtual objects such as 3D models and other media related to the real world can be seen through the camera from a mobile device. The virtual object then tracks the orientation position of the image in real-time so that the user's perspective on the object matches their perspective on the target image. So it appears that the virtual object is part of the real world. (Azhar et al 2014).

\section{RESEARCH METHOD}

The multimedia development methodology consists of six stages, which can be seen in Picture 5, namely concept (conception), design (design), collecting material (material collection), assembly (making), testing (testing), and distribution (distribution) (Ernawati et al. 2017). The research stages can be seen in Picture 5. 


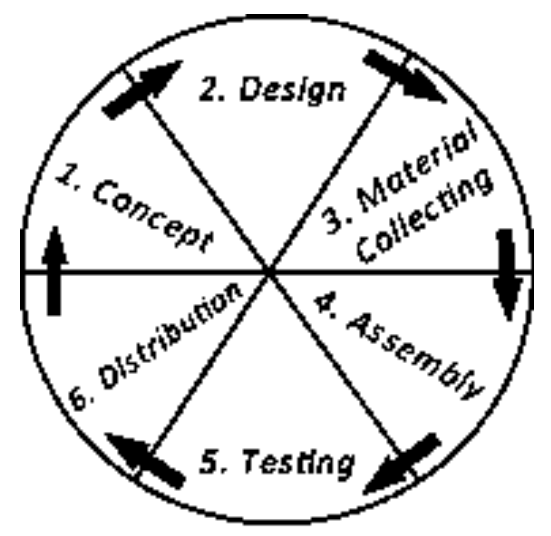

Picture 5. Multimedia Development Stage

\section{1) Concept}

In the initial stages used in building this application, two diagrams are used, namely, Use Case Diagrams and Activity Diagrams where in the Activity Diagram there are three Activities, namely, Starting AR, Quizzes and Instructions. The following is an overview and explanation of each concept:

a) Use Case Diagram

Following is a Use Case Diagram of the application flow, starting when the user first runs the application. In the application system there are several main menus including Menu: About,instructions for use, scan markers, doing exercises and exiting the application, see picture 6 .

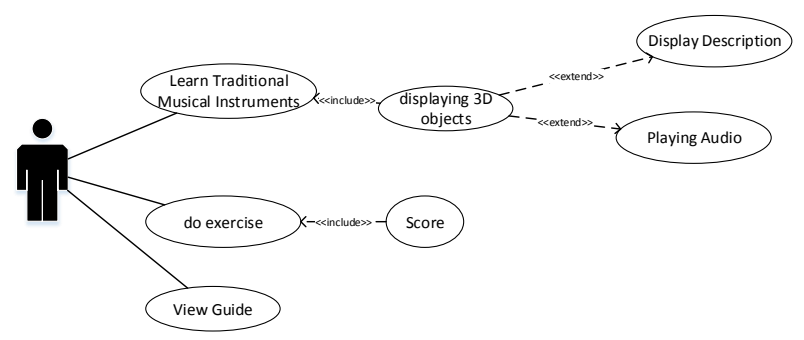

Picture 6. Use Case Diagram

b) Activity Diagram

Picture 7 is an activity diagram of the application Augmented Reality that was built.

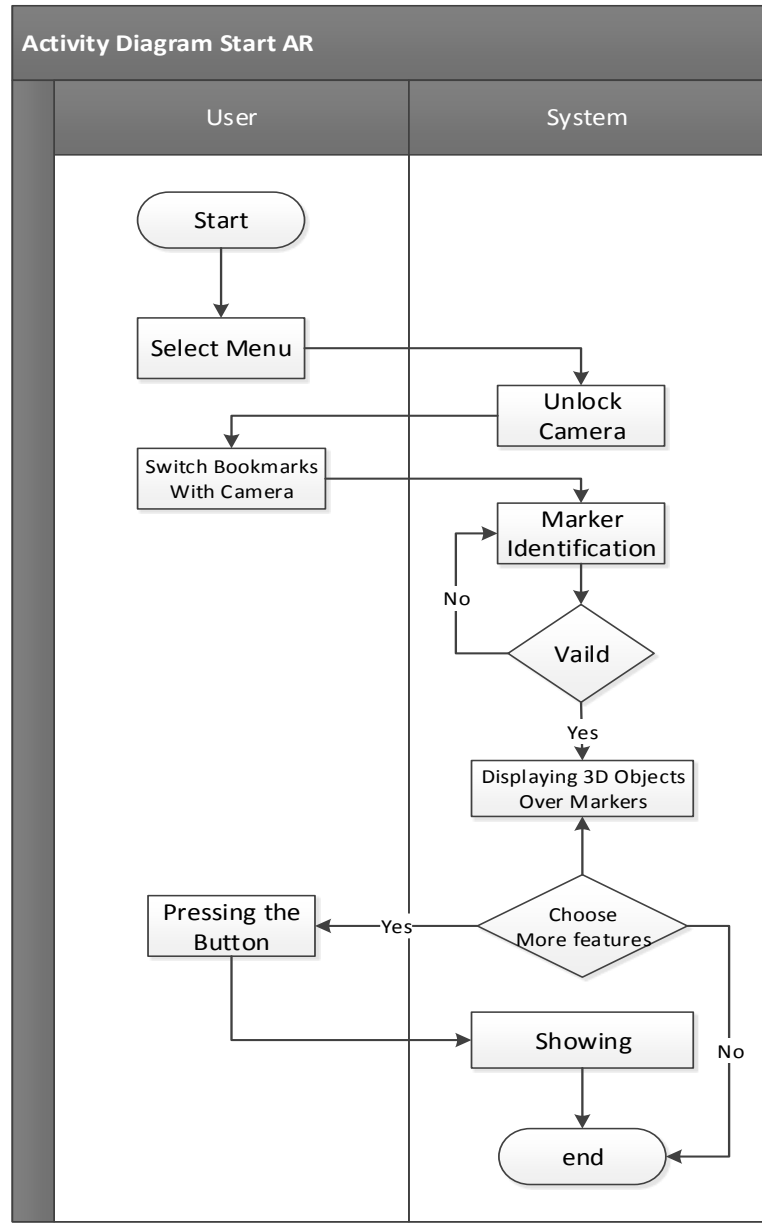

Picture 7. Activity Diagram

\section{2) Design}

Making the view interface of the application and making 3D objects from the planets.

3) Material Collecting

Material Collecting is the stage of collecting materials in accordance with the needs being done. These materials include textbooks, pictures or photos of planets, audios, etc. which can be obtained free of charge or by ordering from other parties according to the design. This stage can be done in parallel with the stage Assembly. However, in some cases, stage materials include textbooks

, pictures or photos of planets, audios, etc. which can be obtained free of charge or by ordering from other parties according to the design. This stage can be done in parallel with the stage Assembly. However, in some cases, stage collecting material and phase of Assembly will be done in a linear and not parallel.

4) Assembly

Phase Assembly is the stage of manufacture of all objects or multimedia materials. Making an application based on stage, design such as design interface.

5) Testing

Phase Testing (testing) is performed after completion of the manufacturing stage (Assembly) to run applications or programs and see if there is a mistake or not. The first stage at this stage is that the test is carried out by the manufacturer or the manufacturing environment itself. 
After testing is complete, testing involving the end use will be carried out. When the final test is carried out, the method used is the method User Acceptance Testing (UAT). User Acceptance Testing is a testing process carried out by users with the output of a test result document that can be used as evidence that the software has been received and has met the requested requirements. 6) Distribution

If the testing phase is successful, this application will be applied to users who will use the application.

\section{RESULT AND DISCUSSION}

\section{A. Assembly}

After the previous process is complete, the next step is to assemble the application, namely the process of building and installing the application to the android platform. After the build process, the application is then installed and run on the smartphone.

\section{Application Build Views}

The application is built using the Android platform so that later the application can be installed and used on smartphones, especially those using the Android operating system, see Picture 8 .

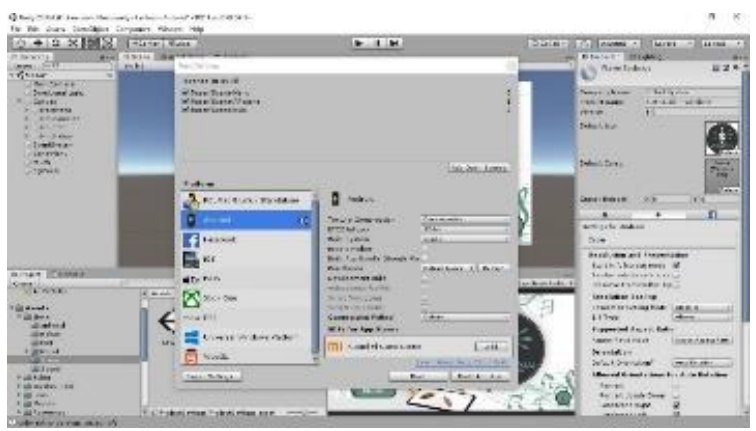

Picture 8 . The process of building applications to the Android platform

\section{Display the application on the smartphone}

After the build process is complete the application is installed on the smartphone then the application is run. The applications that have been opened and the appearance of the menus accessed can be seen in Picture 9.

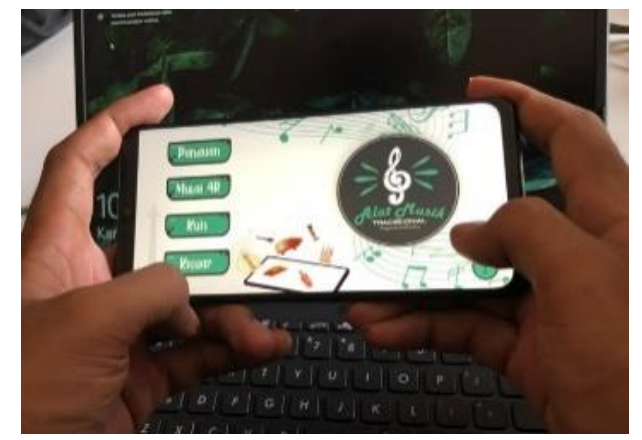

Picture 9. Main Menu Display on Smartphone
From picture 9 it can be concluded that the application has been successfully installed on the smartphone and the application menu display is also responsive on the smartphone used. The next step is the image threshold process can be seen in picture 10 , in each frame doing this process until the image produces black and white colors. In the process of producing black and white, the aim is to find out each shape and pattern of each captured image frame. The tracking process is to detect markers which consist of 4 stages, namely contour exit traction, comer detection, pattern normalization, and template matching.
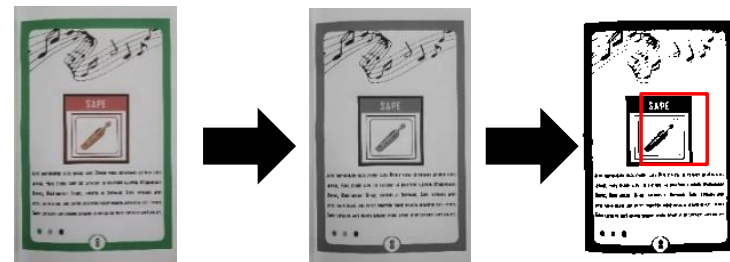

Picture 10. Image Threshold Stage

The counter extraction and corner detection process use black and white images obtained at the stage image threshold to get the coordinates. Picture 11 shows the next stage, which is pattern normalization, which aims to make the marker in a normal position, and then the template matching process can be done correctly.
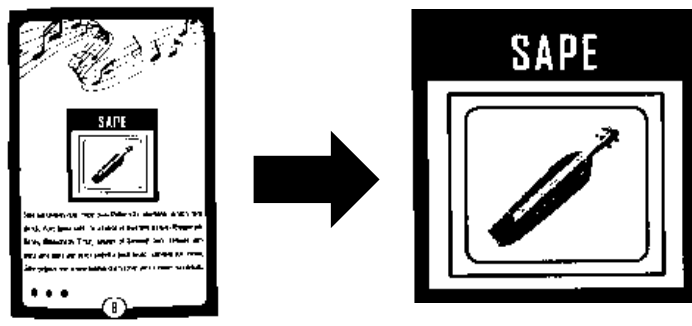

Picture 11. Pattern Normalization and TemplateMatching

The last stage is the relationship between the 3 coordinates, namely the $\mathrm{x}, \mathrm{y}$, and $\mathrm{z}$ coordinates which can be seen in picture 12 which plays an important role in which the $3 \mathrm{~d}$ object will be placed in the position of the previously adjusted object.

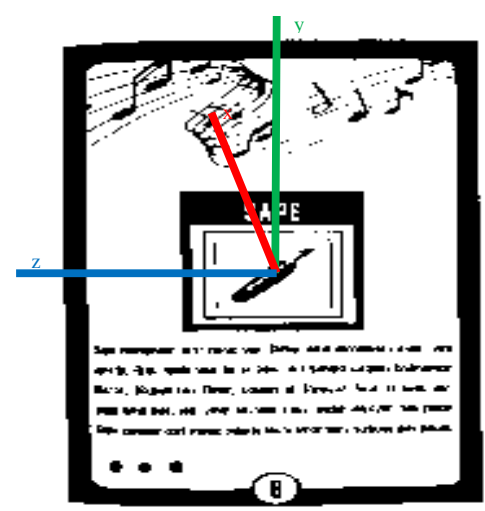

Picture 12. X, Y, And Z Coordinates Point

After that, the $3 \mathrm{~d}$ object will appear if the user points the camera at the marker, in picture 13 you can see the results 
on the smartphone screen when the user points the camera at the marker.

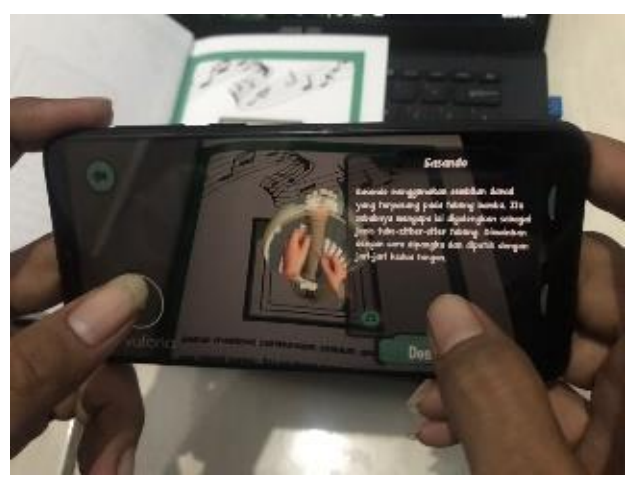

Picture 13. AR Start Menu Display on Smartphone

From the picture 14, the key is that the AR Start menu is also responsive on smartphones and successfully opens the camera and tracking marker used, in the tracking marker process there are also several steps to successfully bring up $3 \mathrm{~d}$ objects. The tracking process on the marker will start from the image input stage, where the processor processes the real-time frame per frame of the user's capture of the image.

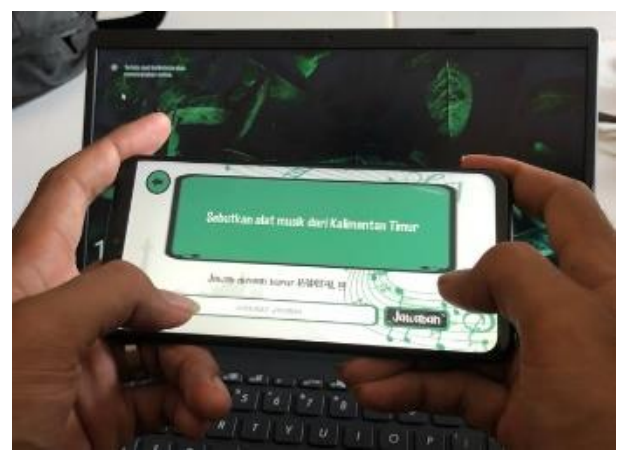

Picture 14. Display Quiz Menu on Smartphone

From picture 15 it can be concluded that the quiz menu is also responsive on the smartphone used and for questions and answers there are also no problems.

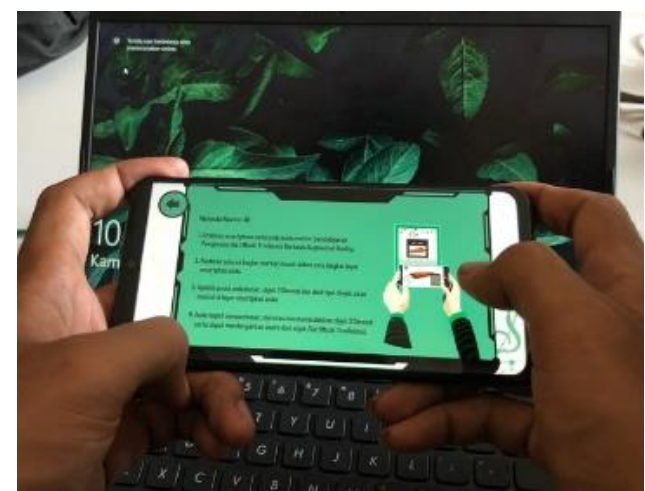

Picture 15. Display of the Guide Menu on a Smartphone

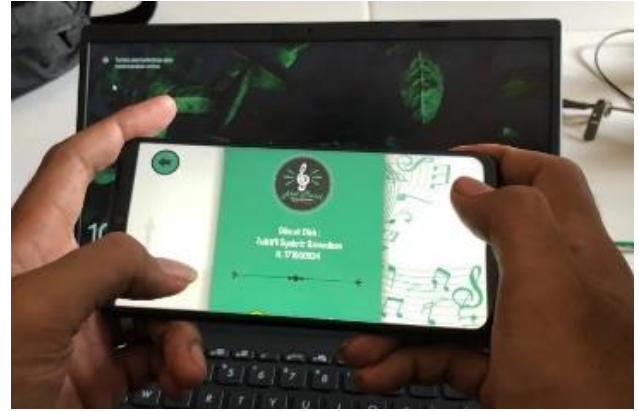

Picture 16. Display Menu Info on Smartphone

From pictures 15 and 16 Key that the guide menu and menu info are also available on the smartphone used. Picture 17 is a book used for applications, the book has been filled with designs from AR markers.
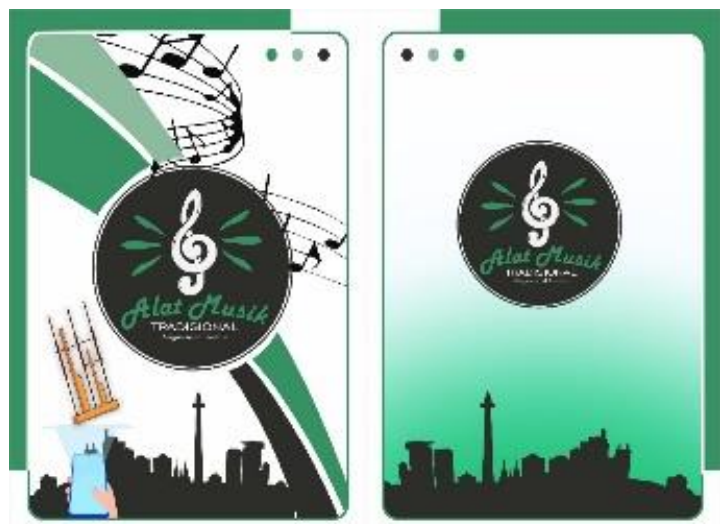

Picture 17. Augmented Reality Traditional Musical Instrument Book

From the pictures, it is said that the application has been successfully installed on the smartphone and the appearance of each application menu is also responsive on the smartphone used.

\section{B. User Acceptance Test Testing}

The next test is the User Acceptance Test. At this stage, the writer conducts the test by conducting a survey directly to the user by conducting a questionnaire. The assessment standards used are as follows.

a. Determination of the score or weight
1) Very Good (VG) has a score of 2
2) $\operatorname{Good}(\mathrm{G})$ has a score of 1
3) Sufficient (S) has a score of 0
4) $\mathrm{Bad}(\mathrm{B})$ has a score of - 1
5) Very Bad (VD) score -2

b. Score Interpretation based on Interval

1) Numbers $0 \%$ - 20\%: Very Bad

2) Numbers $21 \%-40 \%$ : Bad

3) Numbers $41 \%$ - 60\%: Sufficient

4) Numbers $61 \%-80 \%$ : Good

5) Numbers $81 \%$ - 100\%: Very Good The

Weight of the value obtained in the questionnaire results will be included in the percentage formula that will be 
used to calculate the percentageobtained from the test. The percentage formula can be seen in (1)

$$
\begin{aligned}
& \text { Test result }=\frac{\text { Questionnaire Total Score }}{\text { Questionnaire Maximum Score }} \times 100 \% \\
& \text { Test result }=\frac{(\text { VG } x \text { TotalVG })+(G \times \text { TotalG })+(\text { S } \times \text { TotalS })+(B \times \text { Total })+(\text { VD } \times \text { TotalVD })}{\text { Number of Respondents } \times \text { Number of Questionnaires } \times \text { Highest Score Weight }} \times 100
\end{aligned}
$$

The percentage obtained from the results of calculations using the formula above will be adjusted to the standards that have been shown previously, in the presence of Covid-19 in the absence of Class V students, the respondent or system testing. So that it can be concluded whether the application has been well received or not

The questionnaire consists of several questions and is given to teachers of Arts, Culture, and Crafts ( $\mathrm{ACaC})$. The test results can be seen in table 6 .

\begin{tabular}{|c|c|c|c|c|c|c|}
\hline \multirow[t]{2}{*}{ Question } & \multicolumn{5}{|c|}{ Response } & \multirow[t]{2}{*}{ Total } \\
\hline & VG & $\mathbf{G}$ & $\mathbf{A}$ & $\mathbf{B}$ & VB & \\
\hline How about the application logo? & 8 & 2 & & & & 10 \\
\hline How about 3D objects in this application? & 7 & 3 & & & & 10 \\
\hline How do the buttons in this application function & 8 & 2 & & & & 10 \\
\hline How does the sound of the music used in this application? & 8 & 2 & & & & 10 \\
\hline How to design the appearance of each panda page of this application? & 8 & 2 & & & & 10 \\
\hline $\begin{array}{l}\text { How is the explanation of the information for each material in this } \\
\text { application? }\end{array}$ & 6 & 4 & & & & 10 \\
\hline How do traditional musical instruments sound in this application? & 8 & 2 & & & & 10 \\
\hline $\begin{array}{l}\text { How is the cover design of the introduction to the traditional musical } \\
\text { instruments used? }\end{array}$ & 7 & 3 & & & & 10 \\
\hline How is the marker design in the book used? & 8 & 2 & & & & 10 \\
\hline How is the material information in the book? & 7 & 3 & & & & 10 \\
\hline \multicolumn{6}{|l|}{ Total } & 100 \\
\hline
\end{tabular}

Table 6. User Acceptance Testing for Teachers and Students

Based on the results of the questionnaire above, it is known that this application is already running well. The value obtained from the UAT test on teachers andstudents is as follows.

Very Good (VG): 53

Good $(\mathrm{G}) \quad: 41$

Average (A) : 6

$\operatorname{Bad}(\mathrm{B}) \quad: 0$

Very Bad (VB) : 0

After getting the results from the questionnaire, the following calculation results are obtained:

$$
\begin{aligned}
\text { Test result } & =\frac{(2 \times 75)+(1 \times 25)+(0 \times 0)+(-1 \times 0)+(-2 \times 0)}{10 \times 2 \times 10} \times 100 \% \\
& =\frac{172}{200} \times 100 \% \\
& =86 \%
\end{aligned}
$$

Results based on the calculation using the above formula, it can be ascertained that the results of the UAT on the application are very good and can be used.

\section{CONCLUSION}

The application was successfully built by applying augmented reality technology using the Unity game engine and Vuforia SDK which displays a visualization of traditional musical instruments in the form of 3D animated objects. The app also has a feature that displays descriptions of the planets and plays audio of each of the traditional musical instruments. The application also provides an educational game feature for training about traditional musical instruments. It is hoped that it can help students understand the material provided. Successfully implemented image-based tracking using 4 stages, namely contour extraction, angle detection, pattern normalization, and template matching. So that it brings up 3D objects of traditional musical instruments. Based on the responses, the score was $86 \%$, so it can be said that the results of Interpretation of scores based on intervals for the application are very good and can be used.

\section{REFERENCES}

Azhar, N. F., Cahyono, E. B., Kom, S. M. T., Wicaksono, G. W., \& Kom, S. (2014). Pemanfaatan Augmented Reality Untuk Game " Ranger Target" Fps Berbasis Android Menggunakan Unity 3D Dan Vuforia Sdk.

Ernawati, R. S., Hidayat, E. W., \& Rahmatulloh, A. (2017). Implementasi Teknologi Augmented Reality Sebagai Media Pengenalan Aksara Sunda Berbasis Android. Jurnal Teknik Informatika Dan Sistem Informasi, 3(3), 512-523. https://doi.org/10.28932/jutisi.v3i3.671

Faisal, A., Gunawan, A., Supiandi, A., Suherman, A., \& Kusnadi, I. T. (2018). Aplikasi Pengenalan Batik Tradisional Indonesia Berbasis Android. Jurnal Teknologi Dan Informasi, 8(1), 98-105. https://doi.org/10.34010/jati.v8i1.905

Kurniawan, D. A., Sugiarso, B. A., Elektro, T., Sam, U., \& Manado, R. (2019). Pengenalan Alat Musik Bambu Menggunakan Augmented Reality 3 Dimensi. Jurnal Teknik Informatika, 14(3), 291-302. https://doi.org/10.35793/jti.14.3.2019.24146

Rosadi, M. E., \& Purnomo, I. I. (2018). Rancang Bangun Media Pembelajaran Seni Dan Budaya Suku Banjar Berbasis Augmented Reality. Jurnal Teknologi Informasi Universitas Lambung Mangkurat (JTIULM), 3(2), 53-58.L. (2020). Rancang Bangun 
Media Pembelajaran Augmented Reality Mengenal Alat Musik Degung. Jurnal Teknik Informatika Dan Sistem Informasi, 6(2), 342-353. https://doi.org/10.28932/jutisi.v6i2.2699

Nugraha, I. S., Satoto, K. I., \& Martono, K. T. (2014). Pemanfaatan Augmented Reality untuk Pembelajaran Pengenalan Alat Musik Piano. Jurnal Teknologi Dan Sistem Komputer, 2(1), 62-70. https://doi.org/10.14710/jtsiskom.2.1.2014.62-70

Prasetyo, A. (2020). Pengembangan Media Pembelajaran: Pengembangan Multimedia Interaktif Berbasis Problem Based Learning. Yogi Agung Prasetyo. https://books.google.co.id/books?id=uirRDwAAQ BAJ

Rustandy, O., Pranayama, A., Sutanto, R. P., Studi, P., Komunikasi, D., Seni, F., \& Petra, U. K. (2017). Perancangan Buku Merangkai Bentuk 3D Tentang Alat Musik Tradisional Nusantara Untuk Anak Usia 9-12 Tahun Abstrak Pendahuluan Metode Perancangan.

Satria, B., \& Prihandoko. (2018). Implementasi Metode Marker Based Tracking Pada Aplikasi Bangun. Universitas AMIKOM Yogyakarta, 1-5.

Setyawan, R. A., \& Dzikri, A. (2016). Analisis Penggunaan Metode Marker Tracking Pada Augmented Reality Alat Musik Tradisional Jawa Tengah. Simetris : Jurnal Teknik Mesin, Elektro Dan Ilmu Komputer, 7(1), 295. https://doi.org/10.24176/simet.v7i1.517

Sofian, D. I., Syarief, A., Saidi, A. I., Sofian, D. I., Syarief, A., \& Saidi, A. I. (2020). Pengembangan Aplikasi Mobile Pengenalan Alat Musik Tradisional Betawi Dengan Memanfaatkan Teknologi Augmented Reality. 3(1), 1-14. 